\title{
Document details - Impact of halal labeling on brand image on cosmetic product
}

1 of 1

$\rightarrow$ Export $\Perp$ Download More...>

Cited by 0 documents

IEEE International Conference on Industrial Engineering and Engineering Management

Volume 2020-December, 14 December 2020, Article number 9309916, Pages 883-887

2020 IEEE International Conference on Industrial Engineering and Engineering Management, IEEM 2020; Virtual, Singapore; Singapore; 14 December 2020 through 17 December 2020; Category numberCFP20IEI-ART; Code 166486

Impact of halal labeling on brand image on cosmetic product(Conference Paper)

Lestari, F., Hertina, Ritia, L., Riandika, I.N., Mas'Ari, A.

aSultan Syarif Kasim State Islamic University, Department of Industrial Engineering, Riau, Indonesia

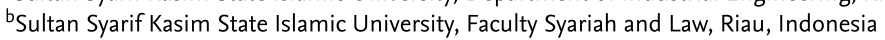

nform me when this document is cited in Scopus:

Set citation alert > Set citation feed >

\section{Abstract}

Indonesia has the largest number of Muslims in the world. Consequently, the halal product market has a high demand from customers. In addition, Halal Brand image is one of the company's strategies to attract many consumers. The purpose of this study is to measure the impact of halal labeling on brand image. The case study of this research was conducted in Indonesia by making cosmetic products that have halal labeling. This research used quantitative methods with a structural equation modeling approach and has 200 sample data. The results of this study found that the performance of the halal labeling had a significant effect on the brand image of halal product cosmetics of $97.4 \%$. The implication of this research shows that the inclusion of halal labeling on cosmetic products has a good effect on brand image. Further research is suggested to conduct a study of product name selection to implement the concept of halal on the product. It aims to increase consumer confidence in buying cosmetic products. (C) 2020 IEEE.

SciVal Topic Prominence (i)

Topic: Brand Equity | Co-Branding | Branding Strategy

Prominence percentile: $97.321 \quad$ (i)

Author keywords

Brand image Cosmetic product Halal labeling Structural equation modeling

Indexed keywords

Engineering controlled Cosmetics

terms:

Engineering uncontrolled Brand image Company's strategy Cosmetic products Halal products Product name
terms

Quantitative method Sample data Structural equation modeling

Engineering main

heading:

Image processing

Funding details

Funding text

The authors thanks to the Ministry of Religious Affairs Republic of Indonesia and Sultan Syarif Kasim State Islamic University which supported this research.

ISSN: 21573611

ISBN: 978-153867220-4

Source Type: Conference Proceeding

Original language: English
DOI: 10.1109/IEEM45057.2020.9309916

Document Type: Conference Paper

Publisher: IEEE Computer Society
Related documents

Find more related documents in Scopus based on:

Authors > Keywords > 
About Scopus

What is Scopus

Content coverage

Scopus blog

Scopus API

Privacy matters
日本語に切り替える

切换到简体中文

切換到繁體中文

Русский язык

Customer Service

ELSEVIER

Terms and conditions $\pi \quad$ Privacy policy $\pi$

Copyright $\odot$ Elsevier B.V $\boldsymbol{\lambda}_{\text {. }}$. All rights reserved. Scopus ${ }^{\circledR}$ is a registered trademark of Elsevier B.V.

We use cookies to help provide and enhance our service and tailor content. By continuing, you agree to the use of cookies.

Q RELX

Help

Contact us 